\title{
Från kantonister till revolutionärer - judisk historia i Finland
}

\author{
Book REVIEW
}

André Swanström, Judarna och toleransens psykohistoria i Storfurstendömet Finland 1825-1917, Kyrkohistoriska arkivet vid Åbo Akademi, Meddelanden 47 (Åbo Akademi 2016), $130 \mathrm{~s}$.

André Swanström utgår från begreppet "tolerans": "Vilka faktorer bidrog till uppkomsten av toleranta eller intoleranta attityder i förhållande till judarna på r 8oo-talet då Finland var ett autonomt storfurstendöme i det ryska kejsardömet?” ( I).

Infallsvinkeln är psykohistoria. "Faktorerna" som Swanström skriver om är inflytelserika aktörers personlighetsdrag. Han hävdar att tolerans och intolerans inte bör uppfattas som en effekt av strukturella, ekonomiska och ideologiska faktorer, utan som uttryck för intensiva mänskliga känslor.

I det första kapitlet, "Nikolaj I och kantonisterna" visar författaren hur judarna blev en del av det ryska samhället, men i intoleransens tecken, som objekt. Kanton var namnet på uppbådsdistrikt där judiska pojkar, ursprungligen föräldralösa barn, rekryterades för militärtjänst. Det första uppbådet åren I827-I829 omfattade 1862 individer. Judarna skulle "reformeras genom militär utbildning, hård disciplin och standardisering" ( 16 ). Införandet av denna värnplikt, som omfattade 25 år, var ett "psykohistoriskt drama": "I de östeuropeiska judarnas kollektiva minne är det endast pogromerna som

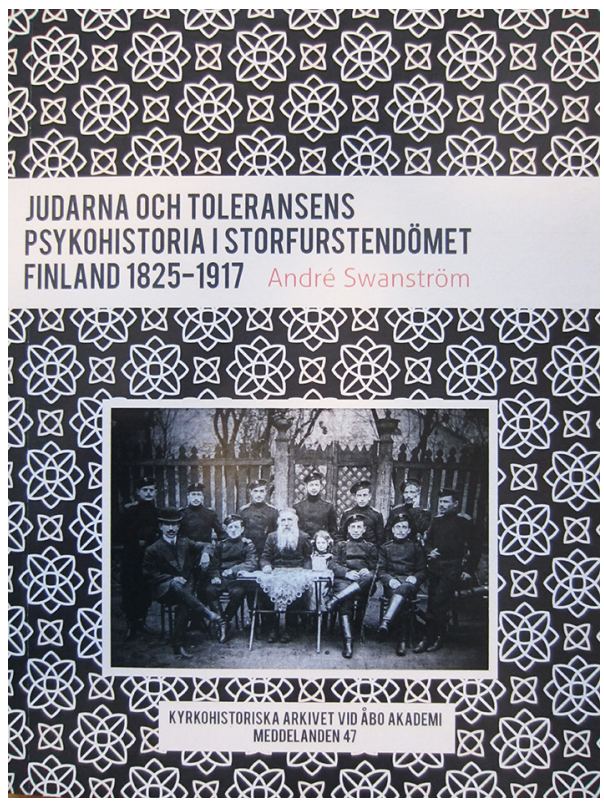

kan mäta sig med den bitterhet som kantonistsystemet genererade" ( 7 7-1 8).

Swanström ser kantonistsystemet som uttryck för Nikolaj I:s personlighet. Dennes socialisering i en auktoritär våld- och bestraffningspedagogik i kombination med tydliga fobier - i detta fall rädsla för allt som hade med eld och explosioner att göra - resulterade i en politik där samhället skulle organiseras som ett härläger. Här fanns inte plats för någon tolerans, men enligt Swanström var det inte fråga om antisemitism i sig: "Judarna och deras ställning i det avlägsna storfurstendömet Finland stod kanske inte högt på tsarens intoleransagenda, 
men de fick sin givna andel av ukaser och kejserliga brev som kom att bilda grunden för kommande decennier av varierande diskriminering" (42).

Swanström ger en rimlig tolkning av Nikolajs beteende i rollen som kejsare, och därmed även av Nikolajs politik gentemot judarna som instrumentell - och totalt utan tolerans.

Den individinriktade psykohistoriska analysmetoden använder Swanström också i de följande kapitlen. Det om "Judemissionen" - titeln är självdefinierande - har fyra individer i fokus: Carl Henrik Alopaeus, veterinären Anders Silfvast, Frälsningsarméns i Finland grundare Hedvig von Hartman samt Louise av Forselles, den senares medhjälpare, sedermera chef för KFUK i Finland. Genom att dessa fyra individer var ståndspersoner måste de betraktas som relevanta representanter för det senare i 8oo-talets "judediskurs" i Finland. Sin infallsvinkel likmätigt skildrar Swanström också dessa personer inifrån. De judar som de ville omvända sökte de två "filantropiskt sinnade societetsdamerna [...] hjälpa, rädda och maniskt reparera" (66).

Det sistnämnda begreppet, "reparation", har Swanström hämtat från psykoanalytikern Melanie Klein. Det är ett slags omvänt Oidipuskomplex hos barnet som hatat sin mor men vill återställa och reparera henne genom att ta hand om en ung kvinna. Swanström ser samma motiv även hos Anders Silfvast, som adopterade en judisk pojke som konverterat och inte återvände till sin familj. Detta framkallade kritik som varande oetiskt och manipulativt. Här vet Swanström inte vad han ska göra med toleransbegreppet: "Vem definierade vad som var tolerant eller intolerant när det gällde judemissionen?" (56-57).

Kapitlet "Antisemiter vid lantdagen" tar upp den arketypiska moderna politiska antisemitismen med konspirationsteorier och kastrationsskräck som psykohistoriska betingelser för judefientlighet hos bondeståndets mångårige ledare Agathon Meurman och hos prästen Torsten
Thure Renvall. Här är det inte fråga om "reparation" utan om ett Oidipuskomplex med "judarna" i faderns roll. Meurmans far var "krävande och dominerande" medan Renvalls var "svekfull och frånvarande" (86). De samtida stereotyperna som komplexet projicerades på var judarna som ute efter världsherravälde respektive judarna som svekfulla förrädare. Intoleransen var så uppenbar att Swanström inte ens nämner ordet.

Kapitlet "Judiska revolutionärer i Finland" förskjuter fokus från judarna som objekt till judar som politiska aktörer. Detta är en annan konstellation än i de tre tidigare kapitlen. Dessa behandlar ju, med Swanströms ord, ”judarna och toleransens psykohistoria i Finland främst under intoleransens företecken" (87).

Medan de tre första kapitlen undersöker förhållandena i Finland som ett slutet system, om ock inom det ryska kejsardömet, gäller analysen i det fjärde kapitlet Finland som exempel på en allmäneuropeisk problematik under tidigt nittonhundratal. Det handlar om nationalismen och den revolutionära socialismen som politiska projekt. Kontexten är här samverkan mellan de finländska aktivisterna i Finska Aktiva Motståndspartiet och de rysk-judiska revolutionärerna. Dessa judar hörde inte till de judiska församlingarna i Finland, men de verkade i Finland.

De legendomsusade orterna Terijoki, Raivola och Kuokkala på Karelska näset var fokus och lokus för möten mellan ryskjudiska revolutionärer och finländska* självständighetsaktivister: "Medan kontakterna i den militära agitationens och pensionatslivets tecken var av en mera inskränkt natur erbjöd samarbetet mellan aktivisterna och /de judiska/ socialistrevolutionärerna en djupare bekantskap och ett utvidgande av toleransens gränser på ett sätt som aldrig tidigare hade förekommit i Finland" (99). Swanström framhåller att de rysk-judiska

* Här syftar adjektivet på strävan att skapa ett självständigt Finland. 
revolutionärernas verksamhet i landet har förbigåtts i historieskrivningen om judarna i Finland.

Toleransbegreppet har inte någon analytisk betydelse i Swanströms undersökning av det finska samhället och judarna under storfurstendömets tid. Så syntes det för recensenten under läsningen av boken sida efter sida. De sista raderna av kapitlet om de judiska revolutionärerna i Finland visar emellertid varför Swanström har valt detta begrepp som tongivande i titeln till sin bok. Det sista tiotalet sidor av detta kapitel handlar om aktivisten Aino Malmberg (I 865I933). Det avslutas: "Om Aino Malmberg kan man säga att hon förde toleransens gränser $i$ förhållande till judar i Finland längre fram än någon annan före henne. Hon delade bostad och liv med exceptionella judiska män och kvinnor för att till slut radera ut alla toleransgränser i ett öppet accepterande och beundrande av de judiska revolutionärerna." ( I I6)

Psykohistorien är en hermeneutisk disciplin, där utgångspunkten inte är hypoteser som kan falsifieras. Swanström har emellertid genom fokuseringen på "tolerans” och "judar" gett en nyanserad och trovärdig skildring av den judiska dimensionen i storfurstendömet Finlands social- och idéhistoria. Hans berättelse om politiskt tongivande personers attityder till judar från intoleransens mörke furste Nikolaj I till toleransens ljusgestalt Aino Malmberg utmynnar i en totalhistorisk syntes av poetisk skönhet. Han avslutar boken med deklarationen att Aino Malmberg "omfamnade både manligt och kvinnligt, ryskt och judiskt på ett sätt som förde toleransens gränser till i finländska förhållanden tidigare oskådade vidder” (I I 8).

\section{KRISTIAN GERNER}

Kristian Gerner är utländsk ledamot av Finska Vetenskaps-Societeten och professor emeritus i historia vid Lunds universitet. Hans forskning och publicistik rör historia, kultur och politik i Norden, Centraleuropa och Sovjetunionen/Ryssland med särskild fokus på 1900och 2000-talen. Han har skrivit om Rysslands judar i monografin Rysslands historia, Historiska Media 2017. 